\title{
較正用基準点チャートの設定誤差を考慮した カメラパラメータ較正誤差の定式化*
}

\author{
村上宙之*1, 野村由司彦*2 \\ 藤 本 貴 史 ${ }^{* 3}$, 松 井 博 和*1
}

\section{Formulation of Camera Parameter Calibration Error Caused by Fiducial Points Setup Error}

\author{
Michinobu MURAKAMI, Yoshihiko NOMURA*4, \\ Takashi FUJIMOTO and Hirokazu MATSUI \\ *4 School of Engineering, Mie University, \\ 1577 KurimaMachiya-cho, Tsu-shi, Mie, 514-8507 Japan
}

\begin{abstract}
Some important parameters are called the camera parameters. They include the principal point, which is the intersection of the optical axis of a camera with the image plane, the principal distance, which is the distance between the center of the lens and the image plane, and the length of 1 pixel on the image plane. The information of the line of sight used for 3D measurements is obtained by transforming the position of the object's image using the above described camera parameters. Highly accurate $3 \mathrm{D}$ measurements are required to calibrate the camera parameters. In a 2-plane calibration method, a calibration fiducial chart containing fiducial points, whose positions on the plane are assumed to be known, is moved in the depth direction, and pictures of the calibration fiducial chart are taken before and after the motion. Here, position and orientation errors of the fiducial chart, referred to "setup errors" in this paper, greatly affect calibration accuracy. In this paper, the authors formulate the relationships between the setup errors of the calibration fiducial chart and calibration accuracy.
\end{abstract}

Key Words: Camera Parameter, 2-Plane Calibration Method, Calibration Error, Setup Error, Formulation

\section{1. 緒}

カメラを用いて三次元計測を行う場合，まず，主点 座標, 画面距離, 撮像面の 1 画素の長さ, レンズの歪 曲係数などのカメラパラメータの值に基づいて, 対象 が写っている像の画像座標から対象に向から視線方向 （視角）を求める. 次に，例えばステレオ視の場合に は, 相異なる 2 点から求めた視線方向の情報に基づい て, 三角測量の原理を適用して, 対象の三次元位置を 求める. そのため, 三次元位置計測を高精度に行うに は, 対象の特徴点が写っている像の画像座標を精度良 く計測するだけでなく, カメラパラメータも精度良く 較正する必要がある.

その手法としては，基準点の形状や位置・姿勢が既 知であるとの前提を置いて, 較正用基準点群を撮像し て得られた画像座標からカメラパラメータを較正する ことがょく行われている.この較正方法においては，

\footnotetext{
* 原稿受付 2008 年 3 月 21 日.

*1 三重大学大学院工学研究科(业514-8507 津市栗真町屋町 1577).

*2 正員, 三重大学大学院工学研究科.

*3 鈴鹿富士ゼロックス (株) (亚519-0393 鈴鹿市伊船町 1900).

E-mail : nomura@mach.mie-u.ac.jp
}

較正用基準点群の設定方法や較正精度の定式化が重要 な研究課題となる. 較正精度を明らかにする研究とし ては, 文献 [1〜3] が挙げられるが, これらはいずれ も, 観測した画像座標に誤差が生じたとき, カメラパ ラメータにどのような誤差をもたらすかという観点で 検討したものである. また，基準点の最適な設定方法 にまで検討を進めた研究もある. 文献 [4]では，較正 用基準点を配置したチャートを傾ける方式を前提とし て, 画面距離の較正誤差を最小化する最適傾きを求め ている. 一方, 文献 [5９］では，基準点チャートを移 動させる方式を前提として, 較正誤差を最小化する, 最適移動量を求めている。

本論文は, 上記の研究 [5～9] と同様に, 多くの較正 法の中で，最も簡便な方法の一つである，二平面較正 法を対象として, 較正精度を定式化する研究を発展さ せたものである. すなわち, 上記の研究では, 図 1(a) のように基準点を配した較正用基準点チャートを近位 置から遠位置に移動させる際に, 較正用基準点チャー トの平面に対して垂直な方向で, 正確に一定距離だけ 移動させることを仮定し, 基準点の画像座標の観測誤 
差のみを考慮して，較正精度を定式化していた．なお， この観測誤差としては, 入力した画像から, 画像処理 で基準点の重心位置を求める際に生じた誤差や, 較正 用基準点チャートの平面内に描かれている基準点の位 置の誤差を一括して扱ってきた。これに対して，実際 に較正を行う場合, 正確に平行移動させることは困難 であり, 多かれ少なかれ図1(b)のように少し傾いてし まうことは避けられない，傾きだけでなく，移動量も 大きかったり小さかったりする.すなわち，較正用基 準点チャートの位置・姿勢の設定值には誤差 (設定誤 差とよぶ）が生じる. そして, その設定誤差は, カメ ラパラメータの較正值にも伝播する.

そこで本論文は，このように実際に較正を行う作業 に際して生じる, 較正用基準点チャートの位置・姿勢 の設定誤差の要因を取り上げ, カメラパラメータ, 特 に画面距離の較正精度への影響を定式化するものであ る.ここで特に画面距離を取り上げた理由は，3次元 計測を目的とする場合, 多数のカメラパラメータの中 で, 画面距離の精度を確保することが格段に重要であ るということによる $[7,8]$.

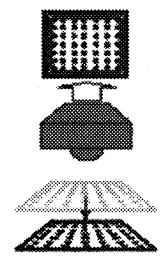

(a) Ideal condition

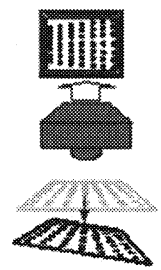

(b) Real condition
Fig. 1 Setup error of the calibration fiducial chart after translation

\section{2. 較 正 対 象}

2.1 カメラモデル 複数のレンズから構成され ている通常のカメラにおいても, 三次元世界から見た ときの主点, すなわち前側主点と, 撮像面から見たと きの主点, すなわち後側主点を想定することにより, ピンホールカメラモデルによる透視投影関係が適用で きる. そこで, 本論文でもピンホールカメラを対象と する (図 2 参照).このとき, $l$ 番目の基準点の画像 座標の計算值 $\vec{U}_{c, l}$ は, 透視投影関係により,

$$
\vec{U}_{c, l}=\vec{C}+F\left[X_{l} / Z_{l} Y_{l} / Z_{l}\right]^{T}
$$

と関係付けることができる. $\vec{C}, F$ は, カメラパラメー タであり, それぞれ, 主点座標と画面距離である. (詳 しくは 2.2 で定義する.)

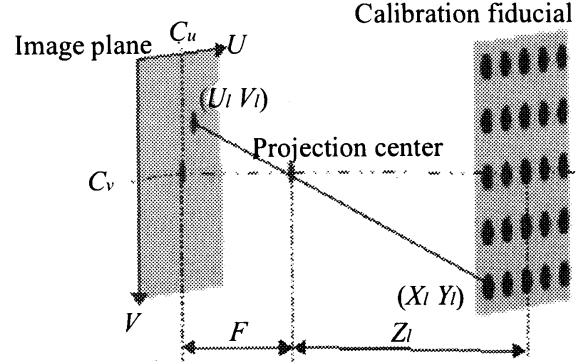

Fig. 2 Camera model

2.2 カメラパラメータ 本論文の前提とするピ ンホールカメラモデルにおいては, 較正対象とするカ メラパラメータは，投影中心の撮像面上の射影である 主点の座標 $\vec{C} \equiv\left[C_{u} C_{v}\right]^{T}$, 撮像面と投影中心間の距離 である画面距離 $F$, ならびに 1 画素の幅と高さの比 $P \equiv S_{u} / S_{v}$, 合計 4 個の内部パラメータである. それ らを図 3 に示す.

上記の 4 つの内部パラメータを較正するためには, 以下に述べる 6 個の外部パラメータも同時に較正しな ければならない，それらは，カメラ座標系に対する世 界座標系の並進ベクトル ${ }^{c} \vec{T}_{w} \equiv\left[T_{x} T_{y} T_{z}\right]^{T}$, 姿勢を表 す回転行列 ${ }^{c} R_{w}$ を与える 3 個の回転角度 $\phi, \theta, \psi$ で ある. ${ }^{c} \vec{T}_{w}$ については 3 章の式 (8) で定義する. $\phi$, $\theta, \psi$ は, それぞれ, 2.3 節の ${ }^{c} X,{ }^{c} Y,{ }^{c} Z$ 軸回りの回 転角度と定義する）以下では, 表現の簡単化のため, 内部パラメータと外部パラメータを未知パラメータベ クトルとして,

$$
\vec{x} \equiv\left[\vec{x}^{(i n) T} \vec{x}^{(e x) T}\right]=\left[\left[C_{u} C_{v} F P\right]\left[T_{x} T_{y} T_{z} \phi \theta \psi\right]\right]^{T}
$$

とまとめる.

なお, 画像歪曲は重要なカメラパラメータの一つで あるが, 文献 [12]のように上記の内部パラメータから 分離して較正できるので, 較正の対象から除外する.

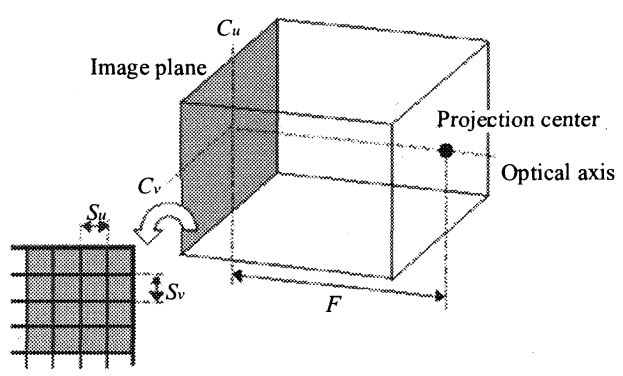

Fig. 3 Camera parameters to be calibrated 
$2 \cdot 3$ 二平面較正法と前提条件 本論文では最も 簡便な較正方法の一つである二平面較正法を対象とし ている. 図 4 に二平面較正法の概要を示す.

較正用基準点チャートは縦・横の間隔 $l_{c}$ で基準点が 配置された平面である. また, 座標系は図 4 , 図 5 に 示すように, カメラの投影中心に三次元カメラ座標系 （以下，3D カメラ座標系とよぶ）の原点を設定し, 近 位置での較正用基準点チャートの中心に三次元世界座 標系の原点を設定する. 三次元世界座標（以下，3D世 界座標系とよぶ）は, 較正用基準点チャートと平行に 座標軸 ${ }^{w} X,{ }^{w} Y$ をとり, 座標軸 ${ }^{w} Z$ は垂直にとる. 力 メラ座標系は, 撮像面と平行に座標軸 ${ }^{c} X,{ }^{c} Y$ をとり, 座標軸 ${ }^{c} Z$ は光軸と一致するように設定する.

この較正用基準点チャートを図 4 左図のように近位 置 $T_{z}$ で撮影する. 次に, 奥行き方向に変化を持たせ るため, 右図のように，較正用基準点チャートを ${ }^{w} Z$ 軸に沿って $T_{c}$ だけ移動させた遠位置で撮影する.こ のようにして得られた 2 枚の画像を使用してカメラパ ラメータは較正される.ここで,

a) 較正用基準点の配置

b) 較正用基準点チャートの設定

c) 較正用基準点チャートを撮像する際の撮像条件 は較正精度に影響を与える。そそこで，条件 a)につい ては文献 [8] と同様に, 平面状に縦・横等間隔かつ等 個数だけ配置する. それ以外の条件 b), c) に対して は, 代表的な条件として, 次項に述べる前提条件を設 定する.

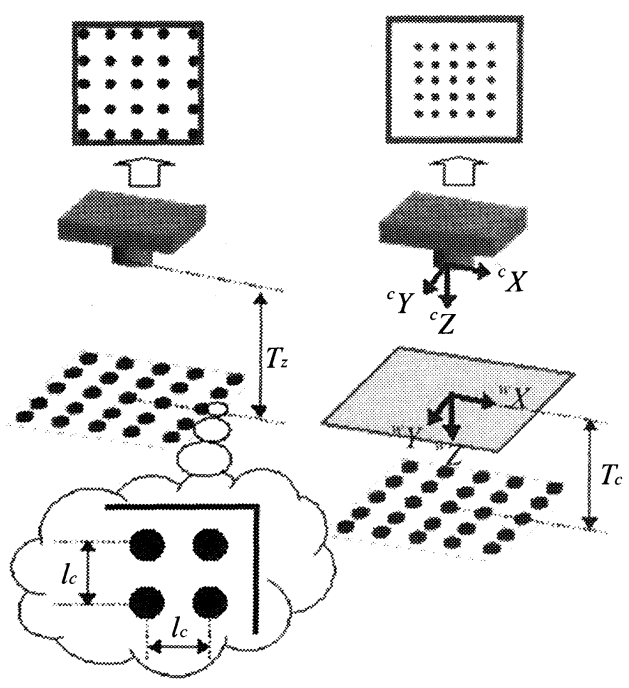

2.3.1 設定に関する前提条件較正用基準点于 ヤートの設定に関して, 以下の前提条件を設定する.

b) 近位置において, 較正用基準点チャートは撮像 面に正対する.

すなわち, 光軸に垂直, かつ光軸と座標軸 ${ }^{w} Z$ を一致 させる.

文献 [8] では較正用基準点チャートを近位置だけで なく，遠位置でも撮像面に正対させることを仮定した． しかし，実際に較正を行う場合，較正用基準点チャー トを所定の遠位置に正確に移動させることは困難であ る. そのため, 較正用基準点チャートの位置・姿勢に誤 差が生じる. 本論文では, このようにして生じる, 較 正用基準点チャートの位置・姿勢の設定誤差 (並進誤 差と回転誤差) と $F$ の較正誤差 $\sigma_{F}^{2}$ との関係を定式化 する.ここで, 実際には, 近位置における正対条件も, 必ずしも満たされない.したがって, 設定誤差（回転 誤差）としては，まず，上記の前提条件 b) からの誤 差, すなわち近位置での正対条件からの角度誤差を考 えなければならない，それに加えて，遠位置でも， ${ }^{w} Z$ 軸に沿って $T_{c}$ だけ並進移動させるという条件からの誤 差, すなわち理想的並進移動からの角度誤差を設定誤 差 (回転誤差)として考えなければならないことにな る. ここで, 前者 (近位置) の角度誤差は固定し, 後 者 (遠位置) の角度誤差を, ある分散 (平均は 0) で ランダムに与えた多数の状況を想定し, さらに各状況 について較正を行ったとしよう．このとき, 前者は外 部パラメータ (回転角度) 較正值に偏り誤差をもたら すが，内部パラメータ較正值には誤差を与えない，こ れに対し, 後者は外部パラメータ (回転角度) 較正值 にランダム誤差をもたらすと同時に, 内部パラメータ 較正值にもランダム誤差をもたらす。 しかし，そのラ ンダム誤差の大きさは近位置での正対条件からの角度 誤差とは無関係である. したがって, 正対条件 b) を 前提として求めた, 較正用基準点チャートの設定誤差 と $F$ の較正誤差 $\sigma_{F}^{2}$ との関係は, 正対条件 b) を満た していない場合にも適用できるものと考えられる.

2.3.2 撮像に関する前提条件較正用基準点于 ヤートを撮像する際の撮像条件に関して, 以下の前提 条件を設定する.

c-1) 近位置において基準点チャートを撮像する際, 基準点は画面全体に撮像される.

c-2）遠位置においても, 基準点チャートは近位置と 同一の基準点が観測される.

Fig. 4 Two-plane calibration method 


\section{3. 座標変換のモデル化}

本章では, 較正用基準点チャートの設定誤差を考慮 して較正誤差を定式化するための前準備として, 以下 に示すように座標系を定義する. (図 5 を参照)

-3D 世界座標系

この座標系の原点は, 近位置における較正用基準点 チャートの中心とし, 各基準点の座標は

$$
{ }^{w} \vec{r}_{l}=\left[{ }^{w} X_{l}{ }^{w} Y_{l}{ }^{w} Z_{l}\right]^{T}
$$

で表す.ここで, 添え字 $l$ は各基準点の順位を示す.

- Ideal3D 運動座標系

この座標系の原点は, 遠位置（較正用基準点チャー トを座標軸 ${ }^{w} Z$ に沿って $T_{c}$ だけ移動させた後の位置を さす）における較正用基準点チャートの中心とし, 各 基準点の座標は

$$
w^{\prime} \vec{r}_{l}=\left[{ }^{w^{\prime}} X_{l}{ }^{w^{\prime}} Y_{l}^{w^{\prime}} Z_{l}\right]^{T}
$$

で表す.

\section{- Real3D 運動座標系}

この座標系の原点は，それぞれ較正用基準点チャー トの設定誤差である並進誤差 $\overrightarrow{\Delta T}=\left[\Delta T_{x} \Delta T_{y} \Delta T_{z}\right]^{T}$, 回 転誤差 $\overrightarrow{\Delta R}=[\Delta \phi \Delta \theta \Delta \psi]^{T}$ を含む，実際に設定された較 正用基準点チャートの中心であり, 各基準点の座標は

$$
w^{\prime \prime} \vec{r}_{l}=\left[{ }^{w^{\prime \prime}} X_{l}^{w^{\prime \prime}} Y_{l}^{w^{\prime \prime}} Z_{l}\right]^{T}
$$

で表す。

座標系の定義に関する, 以上の準備の下で, 設定誤 差を含むカメラ座標を得るための座標変換の手順を 示す.

[手順 1]Real3D 運動座標系から Ideal3D 運動座標系 への変換

$$
w^{\prime} \vec{r}_{l}={ }^{w^{\prime}} R_{w^{\prime \prime}} w^{\prime \prime} \vec{r}_{l}+\overrightarrow{\Delta T}
$$

${ }^{w^{\prime}} R_{w^{\prime \prime}}$ は Ideal3D 運動座標系に対する Real3D 運動座標 系への回転誤差が与える回転行列である.

[手順 2]Ideal3D 運動座標系から 3D 世界座標系への 変換

$$
{ }^{w} \vec{r}_{l}={ }^{w} R_{w^{\prime}}^{w^{\prime}} \vec{r}_{l}+{ }^{w} \vec{T}_{w^{\prime}}
$$

${ }^{w} R_{w^{\prime}}$ は3D世界座標系に対する Ideal3D 運動座標系への 回転であり， ${ }^{w} \vec{T}_{w^{\prime}}$ は 3D 世界座標系に対する Ideal3D 運動座標系への並進ベクトルである.

[手順 3]3D 世界座標系から 3D カメラ座標系への変換

$$
{ }^{c} \vec{r}_{l}={ }^{c} R_{w}^{w} \vec{r}_{l}+{ }^{c} \vec{T}_{w}
$$

${ }^{c} R_{w}$ は3D カメラ座標系に対する 3D 世界座標系への回 転であり, ${ }^{c} \vec{T}_{w}$ は3D カメラ座標系に対する $3 \mathrm{D}$ 世界座
標系への並進ベクトルである. また, ${ }^{c} \vec{r}_{l}=\left[{ }^{c} X_{l}^{c} Y_{l}^{c} Z_{l}\right]^{T}$ である.

本論文では，2 で述べたようにピンホールカメラモ デルを対象としている. 式 (1)に上記のように与えら れる $3 \mathrm{D}$ カメラ座標 $c \vec{r}_{l}$ を代入することで, 設定誤差 を考慮した形で画像座標 ${ }^{c} \vec{U}_{l}$ を求めることができる.

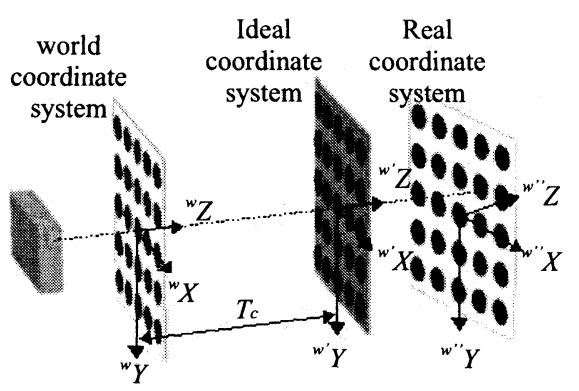

Fig. 5 Coordinate systems

\section{4. 計 算 方 法}

4.1 カメラパラメータ較正法 二平面較正法に より撮影されたすべての基準点の観測画像座標を 1 列 に並べ, 観測画像座標ベクトル

$$
\vec{U}_{a l l} \equiv\left[\vec{U}_{0}^{T} \ldots \vec{U}_{l}^{T} \ldots \vec{U}_{L-1}^{T}\right]^{T}, \vec{U}_{l} \equiv\left[U_{l} V_{l}\right]^{T}
$$

を定義する. また, ピンホールカメラモデルによる透 視投影関係に基づいて計算される基準点の推定画像座 標を 1 列に並べ, 推定画像座標ベクトル $\vec{U}_{\text {est }, \text { all }}$

$$
\vec{U}_{e s t, a l l} \equiv\left[\vec{U}_{c, 0}^{T} \ldots \vec{U}_{c, l}^{T} \ldots \vec{U}_{c, L-1}^{T}\right]^{T}, \vec{U}_{c, l} \equiv\left[U_{c, l} V_{c, l}\right]^{T}
$$

を定義する．このとき, カメラパラメータ較正值は, $\vec{U}_{\text {all }}$ に対して, $\vec{U}_{\text {est }, \text { all }}$ が最もよく一致するように推 定すればよい，例えば，最小二乗法により，

$$
\left\|\vec{U}_{\text {all }}-\vec{U}_{\text {est }, \text { all }}\right\|^{2}=\sum_{l=0}^{L-1}\left\{\left(U_{l}-U_{c, l}\right)^{2}+\left(V_{l}-V_{c, l}\right)^{2}\right\}
$$

を最小化することにより，推定することができる．具 体的には, 線形近似反復解法を適用して推定する. 例 えば, 推定画像座標ベクトルの $l$ 番目の成分 $\vec{U}_{c, l}$ は, $n$ 回目の近似值 $\hat{\vec{x}}^{(n)}$ の近傍で,

$$
\vec{U}_{c, l}(\vec{x}) \approx \vec{U}_{c, l}\left(\hat{\vec{x}}^{(n)}\right)+\frac{\partial \vec{U}_{c, l}\left(\hat{\vec{x}}^{(n)}\right)}{\partial \vec{x}} \cdot\left(\vec{x}-\hat{\vec{x}}^{(n)}\right)
$$

のように線形近似する. これに基づいて, $n$ 次の反復 修正解は,

$$
\Delta \hat{\vec{x}}^{(n)}=\left(A^{(n) T} \Sigma_{U_{\text {all }}}^{-1} A^{(n) T}\right)^{-1} A^{(n) T} \Sigma_{U_{\text {all }}}^{-1} \Delta \vec{U}_{\text {all }}^{(n)}
$$


となる.これにより $n+1$ 番目の近似值は,

$$
\hat{\vec{x}}^{(n+1)}=\hat{\vec{x}}^{(n)}+\Delta \hat{\vec{x}}^{(n)}
$$

と与えられる.ただし， $A^{(n)}$ は，

$$
A^{(n)} \equiv\left[\partial \vec{U}_{e s t, \text { all }} / \partial \vec{x}\right]_{\vec{x}=\hat{\boldsymbol{x}}^{(n)}}
$$

ここで，観測画像座標ベクトル $\vec{U}_{\text {all }}$ には誤差が含ま れる.この誤差を共分散行列 $\Sigma_{U_{\text {all }}}$ としてモデル化す る.このとき, $\Sigma_{U_{\text {all }}}$ が伝播して生じるカメラパラメー タ $\vec{x}$ の較正值の誤差 $\Sigma_{\hat{x}}$ （較正誤差とよぶ）は, 誤差 の伝播則を用い,

$$
\Sigma_{\hat{x}}=\left(A^{T} \Sigma_{U_{a l l}}^{-1} A\right)^{-1}
$$

と表すことができる.ここで， $\Sigma_{\hat{x}}$ はカメラパラメータ $\vec{x}$ の共分散行列, $A$ は収束時の $A^{(n)}$ である. 例えば $\sigma_{C_{u}}^{2}, \sigma_{C_{v}}^{2}$ は主点座標 $C_{u}, C_{v}$ の較正誤差の分散を表し, $\tau_{C_{u} F}$ は $C_{u}$ と $F$ の較正誤差の共分散を表す.

4.2 二つの誤差要因の統合カメラパラメータ 較正における基準点画像座標に関わる誤差 $\sigma_{U_{a l l}}$ の発生 源について考える. 発生源の一つは，較正用基準点を 観測する過程で発生する観測誤差であり，これは共分 散行列 $\sigma_{U_{O b s}}$ で表す。他の一つは, 本論文で課題とし て取り上げている，較正用基準点を近位置から遠位置 に並進移動させる際に発生する較正用基準点チャート の設定誤差である。これは，較正用基準点チャートの 移動後の位置の 3 成分の誤差と姿勢の 3 成分の誤差で あり，それらをまとめて， $\vec{\Delta}=\left[\Delta T_{x} \Delta T_{y} \Delta T_{z} \Delta \phi \Delta \theta \Delta \psi\right]^{T}$ と表すものとする. $\vec{\Delta}$ の各成分は互いに無相関と考 えることができるので, $\vec{\Delta}$ の共分散行列 $\Sigma_{\Delta}$ は要素数 $6 \times 6$ の大きさの対角行列とみなせる.

ここで，本論文における解法のポイントを説明する. この設定誤差は, 結局のところ, 各基準点の画像座標 のばらつきをもたらす。したがって，設定誤差といえ ぞも，それは各基準点の画像のばらつきに置き換えら れる.ここで，設定誤差の例を図 6 に示す

この図を見れば，移動後に生じた奥行き方向一の並 進誤差 $\Delta T_{z}$ や $c y$ 軸周りの回転䛊差 $\Delta \theta$ により, 基準点 の画像座標がばらつくことがわかる.これを一般化す ると, 較正用基準点チャートの位置・姿勢の設定誤差 は，す心゙ての較正用基淮点の位置に対して誤差をもた らし，ひいてはすべての較正用基準点の画像座標に対 して並進・回転変換などの所定の関倸に従って誤差を もたらす.この着想の下，設定誤差の共分散行列 $\Sigma_{\Delta}$ を 基準点の画像座標誤差 $\Sigma_{U_{\text {Seup }}}$ に変換する. すなわち,

$$
\Sigma_{U_{\text {Setup }}}=\left(\frac{\partial \vec{U}_{\text {est,all }}}{\partial \vec{\Delta}}\right) \Sigma_{\Delta}\left(\frac{\partial \vec{U}_{\text {est }, \text { all }}}{\partial \vec{\Delta}}\right)^{T}
$$

ここで,

$$
\frac{\partial \vec{U}_{\text {est }, \text { all }}}{\partial \vec{\Delta}}=\left(\frac{\partial \vec{U}_{\text {est }, \text { all }}}{\partial^{c} \vec{r}}\right) \cdot\left(\frac{\partial^{c} \vec{r}}{\partial{ }^{w} \vec{r}}\right) \cdot\left(\frac{\partial^{w} \vec{r}}{\partial w^{\prime} \vec{r}}\right) \cdot\left(\frac{\partial^{w^{\prime}} \vec{r}}{\partial \vec{\Delta}}\right)
$$

その一方で, 従来から考慮してきた観測誤差行列 $\Sigma_{U_{O b s}}$ は, 通常, いずれの画像座標の観測誤差も互いに無相 関で分散值も等しいと考えられるので, $4 L$ 次元の単 位行列 $I$ に誤差の大きさを表す定数 $\sigma_{U}^{2}$ を乗じ,

$$
\Sigma_{U_{o b s}}=\sigma_{U}^{2} I
$$

とする。

上記の $\Sigma_{U_{O b s}}$ と $\Sigma_{U_{\text {Setup }}}$ は, 二種の異なる発生源を考 慮したものであり，前者は画像座標の観測誤差そのも のの共分散行列であるが, 後者は画像座標とは無相関 の基準点チャートの設定誤差を画像座標の誤差に変換 して得られた共分散行列である.これらの要因は互い に無相関であることから, 共分散行列も互いに相関が ないと考えることができる. それゆえ， $\Sigma_{U_{O b s}}$ と $\Sigma_{U_{\text {Setup }}}$ を加えることにより，二つの誤差要因を統合できる. 統合後の画像座標の誤差の共分散行列 $\Sigma_{U_{a l l}}$ は,

$$
\Sigma_{U_{\text {all }}}=\Sigma_{U_{\text {obs }}}+\Sigma_{U_{\text {Setup }}}
$$

となる.このようにして与えられる $\Sigma_{U_{\text {all }}}$ を式(16)に 代入することにより, 設定誤差を考慮したカメラパラ メ一夕較正誤差の共分散行列 $\Sigma_{x}$ を得ることができる.
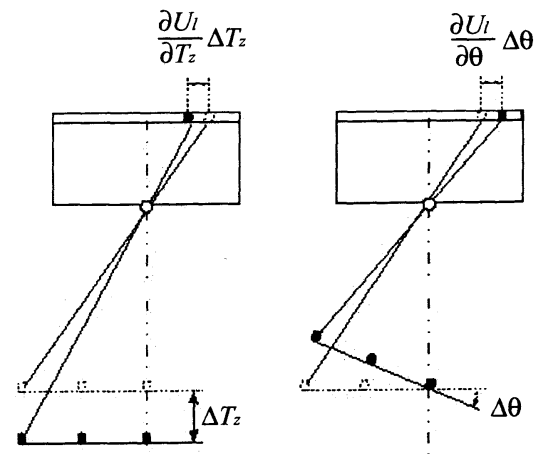

Fig. 6 The effect caused by the setup error $\Delta T_{z}$ and $\Delta \theta$

\section{5. 誤 差 解 析}

5.1 設定誤差 $\Delta T_{x}, \Delta T_{y}$ が較正誤差 $\sigma_{F}^{2}$ に与える影響 基準点の個数や間隔が縦・横方向に等しくなかったり, 1 画素の幅と高さが等しくなかったりすれば, 縦・横の 設定誤差 $\Delta T_{y}$ と $\Delta T_{x}$ が較正誤差 $\sigma_{F}^{2}$ に与える影響は異 
なってくる. しかし, 縦・横の設定誤差 $\Delta T_{y}$ と $\Delta T_{x}$ の 誤差特性は同様であることから, 以下では横方向のみ に注目し, 較正誤差 $\sigma_{F}^{2}$ と設定誤差 $\Delta T_{x}$ の関係を示す.

画面距離 $F$ を推定する場合, その推定值は画像座標 間の距離に依存する。ところが，図 7 に示すように， 設定誤差 $\Delta T_{x}$ が生じても，それによって引き起こされ る各基準点の画像座標の移動量 (これを $\Delta u$ と表す) は全て等しい，そのため, どの基準点の画像座標間で も距離は変化しない. したがって, 設定誤差 $\Delta T_{x}$ は画 面距離 $F$ の較正誤差 $\sigma_{F}^{2}$ に影響を与えない. 以下では, 簡単化した事例，すなわち横方向に隣接する二つの基 準点の画像座標間の距離から画面距離 $F$ を推定する 事例を用いてその特性を例証する， $i$ 番目の基準点に おける画像座標は,

$$
u_{i}+\Delta U=\left\{F\left(i l+\Delta T_{x}\right)\right\} /\left(T_{z}+T_{c}\right)
$$

$i+1$ 番目の基準点における画像座標は,

$$
\left.u_{i+1}+\Delta U=\left[F\left\{(i+1) l+\Delta T_{x}\right)\right\}\right] /\left(T_{z}+T_{c}\right)
$$

である. したがって，(22)-(21) から画面距離 $F$ は,

$$
F=\frac{\left(T_{z}+T_{\mathrm{c}}\right)}{l} \cdot\left(u_{i+1}-u_{i}\right)
$$

と求めることができる. このように, 設定誤差 $\Delta T_{x}$ は 画面距離 $F$ の值に影響を与えない.

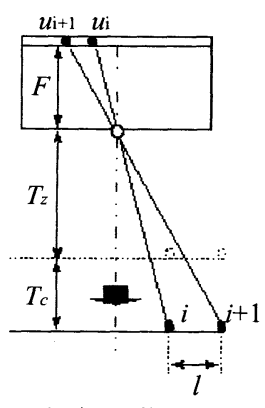

Ideal condition

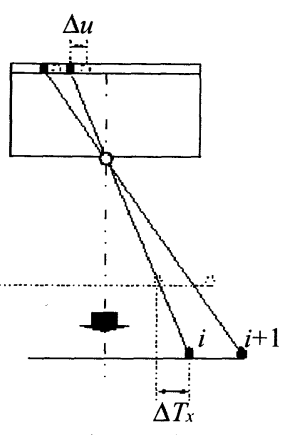

Real condition
Fig. 7 The effect caused by the setup error $\Delta T_{x}$

5.2 設定誤差 $\Delta T_{z}$ が較正誤差 $\sigma_{F}^{2}$ に与える影響 設定誤差 $\Delta T_{z}$ が較正誤差 $\sigma_{F}^{2}$ に影響を与えることは, 設定誤差 $\Delta T_{z}$ によって生じる画像座標の誤差 $\Delta u$ が, 主点から遠い位置に撮像されている基準点ほど大きく なることからも明らかである. 以下では, 較正誤差 $\sigma_{F}^{2}$ と設定誤差 $\Delta T_{z}$ の関係式を導出する.

カメラの視軸が基準点チャートの中心と垂直に交 わっているという, 典型的な条件では, 文献 [8]より,
$\sigma_{F}^{2}$ は $\sigma_{T_{z}}^{2}$ のみに相関を持っていることがわかってい る. このことを利用して， $F$ と $T_{z}$ のみによる部分的 なヤコビアンを式 (16)に適用して，誤差を解析する.

簡単のため, $P=1$ とすると, $F$ と $T_{z}$ のヤコビア ンは,

$$
\left[\begin{array}{ll}
\frac{\partial U_{c, l}}{\partial F} & \frac{\partial U_{c, l}}{\partial T_{z}} \\
\frac{\partial V_{c, l}}{\partial F} & \frac{\partial V_{c . l}}{\partial T_{z}}
\end{array}\right]=\left[\begin{array}{ll}
\frac{c X}{c Z} & \frac{-F^{c} X}{c Z} \\
\frac{c Y}{c Z} & \frac{-F^{c} Y}{c Z}
\end{array}\right]
$$

となる. 上式のヤコビアンを全ての基準点について縦 に連結することにより, パラメータ較正に用いるヤコ ビアンAができる.つまり,

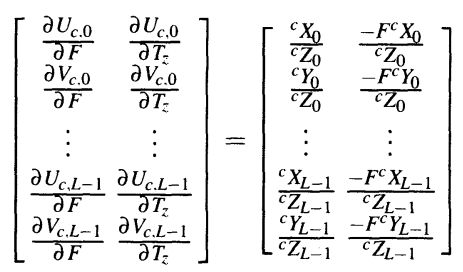

ここで，較正用基準点チャートの近位置と遠位置を， $Z_{\text {near }}$ および $Z_{f a r}$ と表すと, $2 \times 2$ 行列である $A^{T} \Sigma_{U_{\text {all }}}^{-1} A$ の 11 成分, 12 成分, 22 成分はそれぞれ，

$$
\begin{aligned}
& \left.A^{T} \Sigma_{U_{\text {all }}^{-1} A} A\right|_{11}= \\
& \frac{S_{\text {far }}}{\sigma_{u}^{2} Z_{\text {near }}^{2}} \cdot\left\{\frac{\sigma_{u}^{2} Z_{\text {far }}^{2}\left(Z_{\text {near }}^{2}+Z_{\text {far }}^{2}\right)+F^{2} S_{f a r} \Delta T_{z}^{2}}{\sigma_{u}-2 Z_{\text {far }}^{4}+F^{2} S_{f} a r \Delta T_{z}^{2}}\right\} \\
& \left.A^{T} \Sigma_{U_{\text {all }}}^{-1} A\right|_{12,21}= \\
& \frac{-F S_{\text {far }}}{\sigma_{u}^{2} Z_{\text {near }}^{3}} \cdot\left\{\frac{\sigma_{u}^{2} Z_{\text {far }}\left(Z_{\text {near }}^{3}+Z_{\text {far }}^{3}\right)+F^{2} S_{\text {far }} \Delta T_{z}^{2}}{\sigma_{u}-2 Z_{\text {far }}^{4}+F^{2} S_{f} a r \Delta T_{z}^{2}}\right\} \\
& \left.A^{T} \Sigma_{U_{\text {all }}^{-1}}^{-1} A\right|_{22}= \\
& \frac{F^{2} S_{\text {far }}}{\sigma_{u}^{2} Z_{\text {near }}^{4}} \cdot\left\{\frac{\sigma_{u}^{2}\left(Z_{\text {near }}^{4}+Z_{\text {far }}^{4}\right)+F^{2} S_{\text {far }} \Delta T_{z}^{2}}{\sigma_{u}-2 Z_{\text {far }}^{4}+F^{2} S_{f} a r \Delta T_{z}^{2}}\right\}
\end{aligned}
$$

となる，ここで，I，Jは縦・横の基準点数である．ま た, $S_{f a r}$ は文献 [8] で定義しているが,

$$
S_{f a r}=J \sum_{l=0}^{L-1}{ }^{c} X_{l}^{2}+I \sum_{l=0}^{L-1}{ }^{c} Y_{l}^{2}
$$

のように与えられる．このとき， $\sigma_{F}^{2}$ は行列 $\left(A^{T} \Sigma_{U_{\text {all }}^{-1}}^{-1} A\right)^{-1}$ の 11 成分として与えられ,

$$
\sigma_{F}^{2}=\left.\left(A^{T} \Sigma_{U_{a l l}}^{-1} A\right)^{-1}\right|_{11}=
$$

$$
\frac{F^{2}}{\left(Z_{\text {near }}-Z_{f a r}\right)^{2}} \Delta T_{z}^{2}+\frac{\sigma_{u}^{2}\left(Z_{\text {near }}^{4}+Z_{f a r}^{4}\right)}{S_{f a r}\left(Z_{\text {near }}-Z_{f a r}\right)^{2}}
$$

式 (28) の第 2 項は, 設定誤差 $\Delta T_{z}$ を考慮しない場合の 較正誤差 $\sigma_{F}^{2}$ である. したがって, 較正誤差 $\sigma_{F}^{2}$ と設 定誤差 $\Delta T_{z}$ の関係は, 第一項,

$$
\sigma_{F}^{2}=\frac{F^{2}}{T_{c}^{2}} \Delta T_{z}^{2}
$$

で表される. 
$5 \cdot 3$ 設定誤差 $\Delta \phi, \Delta \theta, \Delta \psi$ が較正誤差 $\sigma_{F}^{2}$ に与え

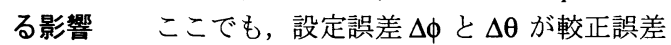
$\sigma_{F}^{2}$ に与える影響は, 同様であることから, 以下では 設定誤差 $\Delta \theta$ が較正誤差 $\sigma_{F}^{2}$ に及ぼす影響のみを考察 する.

具体的には，設定誤差 $\Delta T_{z}$ が較正誤差 $\sigma_{F}^{2} に$ にえる

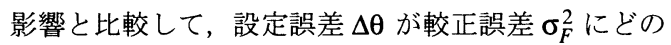
くらい影響を及ぼすか考察し, 設定誤差 $\Delta \theta$ の影響を 無視できることを示す.

5.2 と同様に, $F$ と $T_{z}$ のみによる部分的なヤコビア ンを式(16)に適用して, 解析的に誤差を調べる. ヤコ ビアン $A$ は式(25) となり, $2 \times 2$ 行列である $A^{T} \Sigma_{U_{a l l}}^{-1} A$ の 11 成分, 12 成分, 22 成分はそれぞれ,

$$
\begin{aligned}
& \left.A^{T} \Sigma_{U_{\text {all }}}^{-1} A\right|_{11}= \\
& \frac{2 S}{\sigma_{u}^{2}} \cdot\left(\frac{1}{Z_{\text {near }}^{2}}+\frac{1}{Z_{\text {far }}^{2}}\right)+\frac{F^{2} \cdot E_{\text {etup }}}{\sigma_{u}^{4} Z_{\text {far }}^{6}} \\
& \left.A^{T} \Sigma_{U_{\text {all }}}^{-1} A\right|_{12,21}= \\
& \frac{2 F^{2} S}{\sigma_{u}^{2}} \cdot\left(\frac{1}{Z_{\text {near }}^{4}}+\frac{1}{Z_{\text {far }}^{4}}\right)+\frac{F^{4} \cdot E_{\text {Selup }}}{\sigma_{u}^{4} Z_{\text {far }}^{8}} \\
& \left.A^{T} \Sigma_{U_{\text {all }}}^{-1} A\right|_{22}= \\
& \frac{-2 F S}{\sigma_{u}^{2}} \cdot\left(\frac{1}{Z_{\text {near }}^{3}}+\frac{1}{Z_{\text {far }}^{3}}\right)+\frac{F^{3} \cdot E_{\text {eetup }}}{\sigma_{u}^{4} Z_{\text {far }}^{T}}
\end{aligned}
$$

となる.ここで, $S$ と $E_{\text {Setup }}$ は,

$$
S=\sum_{l=0}^{L-1}{ }^{w} X_{l}^{2}
$$

$$
\begin{aligned}
& E_{\text {Setup }}= \\
& \frac{\sigma_{u}^{2} S^{2} Z_{f a r}^{6} \sin ^{2} \Delta \theta \cdot \Delta \theta^{2}}{\sigma_{u}^{2} Z_{\text {far }}^{4}+F\left(\Sigma^{w} X_{l}^{4}+S Z_{f a r}^{2} \sin ^{2} \Delta \theta+\sum^{w} X_{l}^{2} w Y_{l}^{2} \cos ^{2} \Delta \theta\right) \cdot \Delta \theta^{2}}
\end{aligned}
$$

である. $\Delta \theta$ は微小であるとし, $\sin \Delta \theta \approx \Delta \theta$ とすると, 較正誤差 $\sigma_{F}^{2}$ と設定誤差 $\Delta \theta$ の関係は,

$$
\begin{aligned}
& \sigma_{F}^{2}= \\
& \frac{Z_{\text {near }}^{4} Z_{\text {far }}^{2}}{T_{c}^{2}} \cdot \frac{\sigma_{u}^{2} \Delta \theta^{4}}{4 \sigma_{u}^{2} Z_{f a r}^{4}+4 F\left(\Sigma^{w} X_{l}^{4}+\Sigma^{w} X_{l}^{2 W} Y_{l}^{2}\right) \Delta \theta^{2}+2 F^{2} S Z_{f a r}^{2} \Delta \theta^{4}}
\end{aligned}
$$

となる. ここで, 奥行き比 $M=\left(T_{z}+T_{c}\right) / T_{z}=2.1$, 縦方 向·横方向の基準点数 $N=11$, 主点座標 $C_{u}=C_{v}=1$, 画 面距離 $F=4$ の条件下で, 設定誤差 $\Delta \theta \quad\left(=3^{\circ}=0.051 \mathrm{rad}\right.$ の誤差）と $\Delta T_{z}$ （ $T_{c}$ に対する相対誤差 0.05）が較正誤 差 $\sigma_{F}^{2}$ に与える影響を比較すると, 設定誤差 $\Delta T_{z}$ の影 響が $10^{-2}$ のオーダであるのに対して, 設定誤差 $\Delta \theta$ の 影響は $10^{-8}$ のオーダである. このように, 設定誤差 $\Delta \theta$ が較正誤差 $\sigma_{F}^{2}$ に与える影響は無視できることが わかる.

最後に, 設定誤差 $\Delta \psi$ に関しては設定誤差 $\Delta T_{x}$ の時 と同様で, 設定誤差 $\Delta \Psi$ が生じたとしても画像座標の 誤差 $\Delta u$ はどの基準点においても等しくなるので, 設 定誤差 $\Delta \psi$ は較正誤差 $\sigma_{F}^{2}$ に影響を与えない.

\section{6. シミュレーションによる確認}

先の論文では, 近位置でも遠位置でも同一の基準点 が撮像されるという前提の下で, 近位置では較正用基 淮点チャートが撮像面の全面に撮像され，かつ遠位置 では隣接する基隻点の像の間隔が所定の值になってい るという条件, 寸なわち遠位置を固定して, 近位置の 異なるさまざまな条件の下で, 較正誤差を最小にする 最適な奥行き比 $M$ が 1.6 であることを導いた。この 条件では, $M$ が大きくなるほど, 基淮点の個数は減少 する.

上記とは異なり，近位置を固定して，遠位置の異な るさまざまな条件の下で, 較正誤差を最小にする最適 な奥行き比 $M$ を求めると 2.1 となる. ただし, 近位 置でも遠位置でも同一の基準点が撮像され，近位置で は較正用基準点チャートが撮像面の全面に撮像される といら前提は変わらない. (この条件では， $M$ が大き くなっても, 基準点の個数は変わらない.）本論文で は, 一例として, 後者の奥行き比 $M=2.1$ なる条件下 で較正した場合を取り上げる．また，縋方向・横方向 の基準点数 $N=11$, 主点座標 $C_{u}=C_{v}=1$, 画面距離 $F=4$, カメラ画素の縦横比 $P=1$ とする.

さて, 以下では較正用基隻点チャートの並進誤差 $\Delta T_{z}$

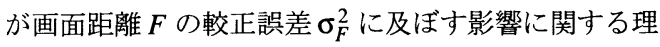
論值をシミュレーションで確認する. 理論式 (29) は, カメラの視軸が基準点チャートの中心と垂值に交わっ ているという典型的な条件と前段落に記載した条件の 下で理論值を求め, 図 8 の実線で示す,一方, 理論式 と同じ条件の下で, 実際のキャリブレーションを想定 して 10 個のパラメータに関するヤコビアンを用いて 式(16)により $\sigma_{F}^{2}$ を求めた結果をシミュレーション值 とよび, 図 8 の・印で示す.この図から, 理論值はシ ミュレーション值に一致していることがわかる.ここ で, 画面距離 $\mathrm{F}$ と相関のあるパラメータとして, 奥 行き方向の移動量の設定誤差 $\Delta T_{z}$ が支配的であるとい う知見に基づいて理論式は導出されていた.これがシ ミュレーション值に一致したことにより, 前提として いた知見と理論式が妥当であることが例証された.

\section{7. 結言}

従来の研究では, 較正用基準点チャートを移動させ る際, 較正用基準点チャートの位置・姿勢に関する設 定誤差が生じないことを前提として，較正用基準点の 画像座標の観測誤差のみを考慮してきた.これに対し て, 本論文では, カメラパラメータ較正への影響要因 として, 較正用基準点の画像座標の観測誤差の要因に 加えて, 較正用基準点チャートの位置・姿勢に関する 


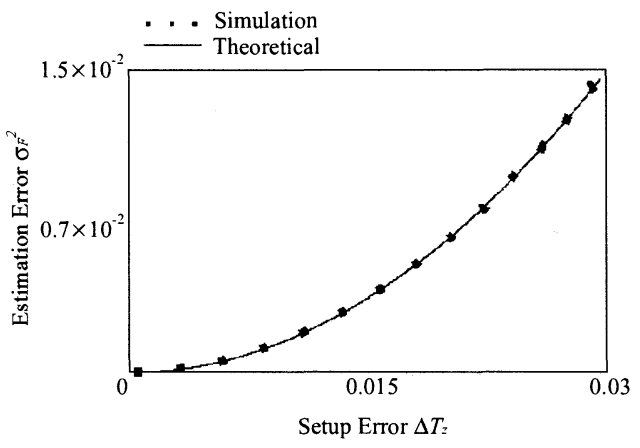

Fig. 8 Relationships between the estimation error of $F$ and the setup error $\Delta T_{z}$

設定誤差の要因を取り上げた，そして，チャートの設 定誤差を観測誤差に変換して报うという着想により, ” 観測值の誤差が未知パラメータの推定值の誤差に伝播 する”という従来の誤差解析の枠組みに基づいて設定 誤差要因をモデル化し，以下の結果を得た。

(1) 並進誤差及び回転誤差などのチャートの設定誤 差が画面距離の較正䛊差に及ぼす影響を簡単な有 理式で定式化した.

(2) チャートの姿勢の設定誤差に因る影響は無視で きることを確認した。

(1)の式を用いることにより, 較正用基準点チャー トの設定誤差を予測したり，逆に，較正誤差見合いで 設定誤差の要求条件を求めたりすることができるよう になる. また，(2)により，チャートの設定に際して は, 回転の精度より, 並進の精度を確保することが重 要であることがわかる.

今後は，三次元計測に対しては，画面距離ほど重要 ではないが, 重要なカメラパラメータである主点の 座標を取り上げ，その較正精度に対する較正用基準点 チャートの設定誤差の及ぼす影響について解明したい．

\section{文献}

(1) Ricolfe-Viala, C.and Sanchez-Salmeron, A.J: "Uncertainty Analysis of camera parameters computed with a 3D pattern ", Proceedings Lecture Notes in Computer Science, Vol 3617, pp.204-211, 2005

(2) Stum, P. et al: " Focal length calibration from two views: method and analysis of singular cases ", Computer Vision and Image Understanding, Vol 99, No.1, pp.58-95, 2005

(3) Lucchese,L: "Geometric calibration of digital cameras through multi-view rectification", Image and Vision Computing, Vol 23, No.5, pp.517-539, 2005

(4) K.Kanatani: "Statistical analysis of focal length calibration using vanishing points ", IEEE Trans.Robotics Automation, 8-6, pp.767-775, 1992
(5) D,Zhang, Y.Nomura, S.Fujii: " Error analysis and optimal setup on camera calibration ", Proc, Asian Conference on Computer Vision, pp.II210-II214, 1995

(6) D,Zhang, Y.Nomura, S.Fujii, "Error Analysis and Optimal Fiducial Mark Setup on Camera Calibration Using Direct Nonlinear Minimization", Transactions of the Japan Society of Mechanical Engineers.C, Vol 61, No.586, pp.252-259, 1995

(7) D,Zhang, Y.Nomura, S.Fujii, "Optimization on Principal Distance Calibration of TV Camera " , The transactions of the Institute of Electronics, Information and Communication Engineers, Vol 79-D-II, No.9, pp.16431645, 1996

(8) T.Fujimoto, Y.Nomura, D,Zhang, "Relationships between the Camera Calibration Accuracy and the Imaging Condition ", Transactions of the Japan Society of Mechanical Engineers.C, Vol 72, No.717, pp.1695-1700, 2006

(9) Y.Nomura, T.Fujimoto, D,Zhang, "A Formulization of Camera-Parameter Calibration Errors and Resultant Visual-Line Estimation Errors" , Transactions of the Japan Society of Mechanical Engineers.C, Vol 71, No.706, pp.1937-1945, 2005

(10) Hayman, E and Murray, D.W: "The Effects of Translational Misalignment when Self- Calibration Rotating and Zooming Cameras", IEEE Trans.Pattern Analysis and Machine Intelligence, Vol 25, No.8, pp.1015-1020, 2004

(11) Wang.L et al:"Error Analysis of Pure Rotation Based SelfCalibration ", IEEE Trans.Pattern Analysis and Machine Intelligence, Vol 26, No.2, pp.275-280, 2004

(12) Y.Onodera, K.Kanatani, " Geometric Correction of Images without Camera Registration ", The transactions of the Institute of Electronics, Information and Communication Engineers, VolJ75D2, No.5, pp.1009-1013, 1991 